\title{
Teachers Caring Behavior and Its Relation with Students Achievement: The Case of East and West Gojjam Secondary Schools, Amhara Region, Ethiopia
}

\author{
Molalign Tamiru* Gebyehu Shiferaw Tesfaye Abebe \\ Department of Education, Debre Markos University, PoBox 269, Debre Markos, Ethiopia
}

\begin{abstract}
The study has tried to investigate the state of teachers caring behavior as perceived by their students and its relation with students' achievement. Descriptive survey with correlational research design was employed. Questionnaire was developed to assess how frequent teachers demonstrate caring behavior. Quantitative data were collected through questionnaire from students and their 2019/2020 academic year first semester achievement records. SPSS version 26 was used to employ descriptive correlational analysis method, besides statistical mean was used to explain the state of caring behavior of teachers while correlation coefficient was employed to elucidate the relation between students' perceived caring behavior of teachers and their achievement (Mathematic and English subjects result out of $100 \%$ ). Thus, the following findings were obtained: the status of perceived teachers caring behavior is found at average level. For some considerable number of caring behavior indicators (items) the status is below the average. Concurrently, the relation between perceived caring behavior and students' achievement is negative and with weak relation. However, differences were observed between female and male students regarding the trend of relation. While females' is found positive, the males' is negative, though the relations were weak for both of them.
\end{abstract}

Keywords: Caring, teachers' caring behavior, students' achievement

DOI: $10.7176 / \mathrm{JEP} / 12-13-05$

Publication date:May $31^{\text {st }} 2021$

\section{Introduction}

Teachers are the key personnel in an educational system because they play a major role in the delivery of quality education; and teaching is a caring and humanizing profession and the primary obligation of teachers is to assist the realization of students' full humanity (Ayers, 1993). Teachers' caring behavior appears to be one of the most important indicator of successful teachers in bringing students' learning (Bahar, 2014). Besides, Bahar contends that there is a direct connection between students who consider their teachers to be caring and the academic performance of those students.

Different writers have explained about indicators of caring behaviors of teachers in different terms but related in meanings. For instance, Lambert (1995) notes that caring behaviors of teachers consist of five basic elements: faith in the student, respect, trust, perceived sincerity, and attentiveness. Similarly, Bulach's, Brown's, and Potter's (1998) identified five factors or categories of teachers caring behaviors that can use to create a caring learning community: the ability to reduce anxiety, willingness to listen, rewarding of appropriate behavior, being a friend, and the appropriate use of positive and negative criticism.

In addition, Bulach, Brown, and Potter (1998) identify caring behaviors which are aligned with Maslow's theory of motivation that reducing Anxiety meets students' security needs, Calling students by name, greeting them as they enter the room, listening and Being a Friend meet their needs of belonging, Rewarding Good Behavior and Appropriate use of Criticism meet students' needs for self-esteem, which allows a student to focus on selfactualization needs so learning can occur. Caring teachers are perceived as caring who demonstrates empathy, understanding and responsiveness (Teven \& Mc croskey, 1997). These attributes (empathy, understanding and responsiveness) of caring teacher represent teacher's capacity to see a situation from the view and feeling of students that the act of learning is more important than the act of teaching; and the teachers' role varies from facilitator to co-learners (Palmer, 2007). Palmer extends that being caring teacher helps teachers to define their selfhood and accordingly it helps them to connect subjects, students and themselves.

Teachers caring behavior is an important factor in education (Gilligan, 1982; Kohn, 2006; Lumpkin, 2007; Noblit, 1993; Noddings, 1984, 1988, 1992; Rogers \& Web, 1991), and it affects the academic outcomes of the students (Goldstein, 1998; Stipek, 2006).

Teachers caring behavior is important to improve students' behavior and help them develop better skills at managing interpersonal problems, which positively affect their ability to learn (Weissberg, Barton, \& Shiver,1997). In addition, it creates a love-based teaching-learning process and enables teachers to reconnect with the powerful and sustaining emotions (Liston and Garrison, 2004). Furthermore, it is also strongly related to students' performance, student connectedness to school, and student perceptions of school safety (Knoell, 2012). In sum, teachers caring behaviors do have the potential to create very important contexts and situations for students' 
development (Pianta et al., 2003).

In Ethiopia the nation claims to make its teachers to be supportive and create safe environment to students [Ethiopian Ministry of Education (EMoE), 2012). This concept of caring (Ryan \& Deci, 2000), among others, is put as a standard for Ethiopian school teachers (EMoE,2012) that impacts certain behaviors of students such as engagement in learning (Pianta et al. ,2012), achievement (Thompson, 2010), anxiety reduction (Saltali, 2013), and the like.

Even though, motivational factors like caring behaviors influence students' academic achievement (Middleton; Boekaerts,2002), and the Ethiopian Education and training policy claims to do so, schools in Ethiopia focused more on technical and cognitive strategies like methods of teaching, teachers' interest (Adane, 2017), parental involvement, peer pressure, attendance, school facilities and stakeholder commitments (Feyera,2014) as factors that influence students' achievement. This technical and cognitive focused education is suspected for ignoring the affective domains of teaching learning process.

So, it is necessary to conduct research further on affective issues like teachers caring behaviors.

\section{Gaps in the existing literatures and Basic questions}

Researchers have surfaced out that different factors influence students' achievements. Among these teachers interests, teaching methods (Adane, 2017); facilities, parental involvement (Feyera, 2014), teachers' professionalism, collegial leadership, community engagement (Abeya, 2017) are some which are identified in Ethiopian context. Other researches indicate that perceived teachers affective support and academic self-efficacy (Sakiz, 2015); and perceived supportive behaviors and teaching styles (Hein, 2012) have strong relation with students' motivation and learning out comes. In addition, Bulach (1998), Deiro (1996) and Noddings (1992) have discovered that when students perceive their teachers as genuinely caring, the resulting relationship significantly influences their motivation to learn.

Though researches conducted students' achievement and its relation with different teachers' and school factors, they still suggest the need to expand the body of research regarding caring behaviors of teachers as determinant of students' achievement.

In Ethiopian context, Molalign (2016) in his qualitative study (conducted in the capital city Addis Ababa) surfaced out the state of teachers caring relationship with students is low and rather teachers focused on coverage of contents, and most of the benefits of students are controlled by teachers. Teachers' caring behaviors and its relation with students' achievement is not yet researched in Ethiopian context. Moreover, in the nation, apart from scares researches, no quantitative study on the area. Therefore, this quantitative study is aimed to examine the state of teachers' caring behavior and its relation with students' achievement in Ethiopian context. In line with this the study has tried to answer the following questions:

$\checkmark$ What is the state of teachers caring behavior as perceived by their students?

$\checkmark$ How strong is the relation between perceived teachers caring behavior and students' achievement?

$\checkmark \quad$ Is there difference in the trend of relation between perceived teachers caring behavior and students achievement as a function of sex?

\section{Methodology}

\subsection{Research Method and Design}

The research method of this study was purely quantitative. Accordingly, it employed descriptive survey and corelational designs. As these designs are systematic and objective (Frankel \& Wallen, 1996), they were useful to describe the state of caring behaviors demonstrated by teachers and its relation with students' achievement. Such design is deductive; and the result is going to be generalized to the larger population.

\subsection{Population and sampling techniques}

The population of this study was students in secondary schools (from grade 9 to 12) of East Gojjam, and West Gojjam in Amhara Regional state. By taking the two zones as clusters, from each cluster two general secondary schools with grades nine to ten were selected by using simple random sampling technique. Again, by using stratified sampling technique, taking grades nine and ten as strata, two classrooms from each stratum were selected through simple random sampling technique. Accordingly, randomly selected students of these classrooms were taken as respondents. The two subjects (English and Mathematics) are selected because both of them are key and compulsory disciplines that students are expected to have recommendable achievement.

\subsection{Instruments and Data Collection Procedure}

Questionnaire

The study employed Bulach's (1998) likert type survey instrument with few modifications in order to adapt it with Ethiopian context. From 26 items of Bulach's survey instruments 20 items which are appropriate to Ethiopian context were selected and besides three more items which suit Ethiopian school environment were added to collect 
perceived teachers' caring behaviors from students. The survey was with three scales ranged from Never (1) to always (3), sometimes (2) included in between. Items of the instrument were translated to Amharic language so as to make provision of responses ease.

In addition, the survey instrument was tasted by pilot study on secondary schools which were not included in the sample of the main study. One hundred eighty questionnaires were distributed to respondents and one hundred seventy-three papers $(96.1 \%)$ were returned back.

Document Review

Students 2019/2020 academic year first semester Mathematics and English subjects results out of 100\% were collected from their rosters.

\subsection{Reliability and Validity of Instruments}

The reliability of instrument was checked by using Cronbach's alpha coefficient of reliability to check the internal consistency of items and how closely related they are. The alpha coefficient for the 23 items was $\alpha=0.81$ and it was high and accepted to proceed data collection. Besides, colleagues and experts in the area have checked the validity of the instrument, as a result some modifications have been made based on the comments given.

\subsection{Analysis of Data}

The study employed quantitative analysis. Mean was used to describe the state of teachers' caring behavior. Pearson's correlation coefficient was utilized to examine and determine the relation between teachers' perceived caring behaviors and students' achievement in terms of grade point (exam result) out of 100\%. SPSS version 26 was employed.

\subsection{Ethical Considerations}

Permission was received from responsible bodies of schools. Respondents were informed about the objective of the study and their responses were kept confidentially. The returned back questionnaires were put in researchers' personal cabinet.

\section{Data Presentation and Analysis}

\subsection{Demographic Data}

From 173 students in the sample, 89 were from West Gojjam zone and 84 were from East Gojjam Zone. Data of all members are presented here by their sex in the following table 4.1

\section{Table 4.1: Respondents by their sex}

\begin{tabular}{|c|c|c|c|c|c|}
\hline & & Frequency & Percent & Valid Percent & Cumulative Percent \\
\hline \multirow[t]{3}{*}{ Valid } & female & 90 & 52.0 & 52.0 & 52.0 \\
\hline & male & 83 & 48.0 & 48.0 & 100.0 \\
\hline & Total & 173 & 100.0 & 100.0 & \\
\hline
\end{tabular}

4.2 The state of teachers caring behavior as perceived by their students Table 4.2 The state of teachers caring behavior

\begin{tabular}{ll|r|r|r|r} 
& $\mathrm{N}$ & \multicolumn{1}{|c|}{ Minimum } & Maximum & Mean & Std. Deviation \\
\hline The state of teachers caring behavior & 173 & 2 & 3 & 2.11 & .267 \\
\hline Valid N (list wise) & 173 & & & & \\
\hline
\end{tabular}

Table 4.2 explains that the mean of the state of teachers caring behavior is 2.11 . This figure indicates that teachers in the sample secondary schools demonstrate caring behavior at the average level, which means they sometimes interact with their students in a caring manner. However, as it is presented in table 4.3, seven (30.4\%) of the twenty-three items such as: informing parents about students' progress, recognition of students' extracurricular activities, displaying of students works, creating good relation with parents, coaching students out of classroom, creating conducive environment for students, and helping students to cooperate with friends are rated below the average. This finding goes with the finding of qualitative study conducted by Molalign (2016) which explains that the state of teachers caring relationship with students is low. But other scholars asserted that teachers must enhance and practice an act of caring (Noddings,2010), stay connected with their students (Garza,2009) and teaching is a caring and humanizing profession that strives for the realization of students' full humanity (Ayers, 1993). To this end Baker and Narula (2012) explains that teaching need to encompass relational responsibilities. 
Table 4.3 The state of teachers caring behavior for each specific item

\begin{tabular}{|l|l|l|}
\hline S.No. & Item & Mean \\
\hline 1 & Our teacher greets us when he/she enters the room. & 2.647399 \\
\hline 2 & Our teacher calls us by our names. & 2.16763 \\
\hline 3 & Our teacher compliments us for good behaviors. & 2.33526 \\
\hline 4 & Our teacher enforces the same rules for all students. & 2.156069 \\
\hline 5 & Our teacher informs our parents about our progress. & 1.67052 \\
\hline 6 & Our teacher recognizes us for academic achievement. & 2.150289 \\
\hline 7 & Our teacher recognizes us for extra-curricular achievement. & 1.947977 \\
\hline 8 & Our teacher displays our works. & 1.884393 \\
\hline 9 & Our teacher provides well-arranged classrooms. & 2.109827 \\
\hline 10 & Our teacher advises us to be ethical & 2.456647 \\
\hline 11 & Our teacher advises us to use our time effectively & 2.49711 \\
\hline 12 & Our teacher supervises us for our academic improvement by creating good relationship & \\
& with our parents & 1.745665 \\
\hline 13 & Our teacher takes a personal interest in what we do outside the classroom. & 1.809249 \\
\hline 14 & Our teacher gives us opportunities to make decisions. & 2.132948 \\
\hline 15 & Our teacher creates an environment where we feel safe. & 1.988439 \\
\hline 16 & Our teacher teaches us at our ability level. & 2.280702 \\
\hline 17 & Our teacher makes time for us before and after school. & 1.485549 \\
\hline 18 & Our teacher asks for our opinion. & 2.040462 \\
\hline 19 & Our teacher returns work promptly with comments. & 2.225434 \\
\hline 20 & Our teacher gives us help when we don't understand or respond. & 2.063584 \\
\hline 21 & Our teacher asks us to help with classroom tasks. & 2.436047 \\
\hline 22 & Our teacher is positive with us. & 2.317919 \\
\hline 23 & Our teacher allows us to have fun. & 1.907514 \\
\hline
\end{tabular}

\subsection{Teachers Caring Behavior and Students Achievement}

The table and the scatter plot below indicate that the relation between perceived teachers caring behavior and students' achievement (in terms of exam result out of 100\%) is negative and very weak relation; and it is nearly zero (-0.079).

Table 4.4: The Relation between the status of teachers caring behavior and students achievement

Extent of teachers caring behavior

$\begin{array}{ll}\text { The state of teachers caring behavior } & \text { Pearson Correlation } \\ & \text { Sig. (2-tailed) } \\ & \text { N } \\ \text { Students } 2019 / 20 \text { academic year } & \text { Pearson Correlation } \\ \text { result out of } 100 \% & \text { Sig. (2-tailed) } \\ & \text { N }\end{array}$

\section{Students 2019/20 academic} year result out of $100 \%$ 


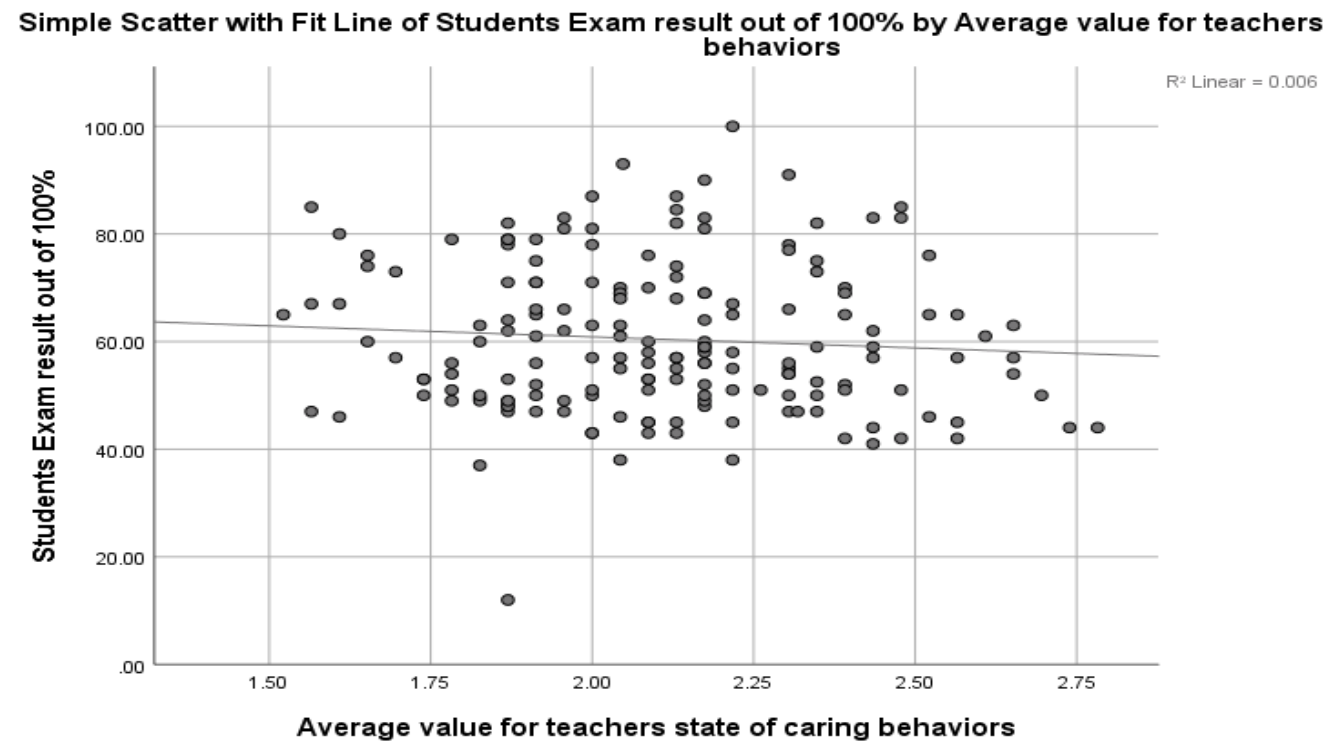

\section{Chart 4.1 Total students scatter plot}

This is aligned with male students' correlation coefficient (-0.123), though the slight difference exists between the two correlation coefficients. But Hein (2012) and Bahar (2014) explains that perceived supportive behaviors of teachers have strong positive relation with students' learning out comes.

\section{Table 4.5: Male students correlation result}

\begin{tabular}{l|l} 
the state of teachers caring & students result out
\end{tabular} behavior of $100 \%$

\begin{tabular}{|c|c|c|c|}
\hline \multirow{3}{*}{$\begin{array}{l}\text { the state of teachers caring } \\
\text { behavior }\end{array}$} & Pearson Correlation & 1 & -.123 \\
\hline & Sig. (2-tailed) & & .269 \\
\hline & $\mathrm{N}$ & 83 & 83 \\
\hline \multirow[t]{3}{*}{ students result out of $100 \%$} & Pearson Correlation & -.123 & 1 \\
\hline & Sig. (2-tailed) & .269 & \\
\hline & $\mathrm{N}$ & 83 & 83 \\
\hline
\end{tabular}

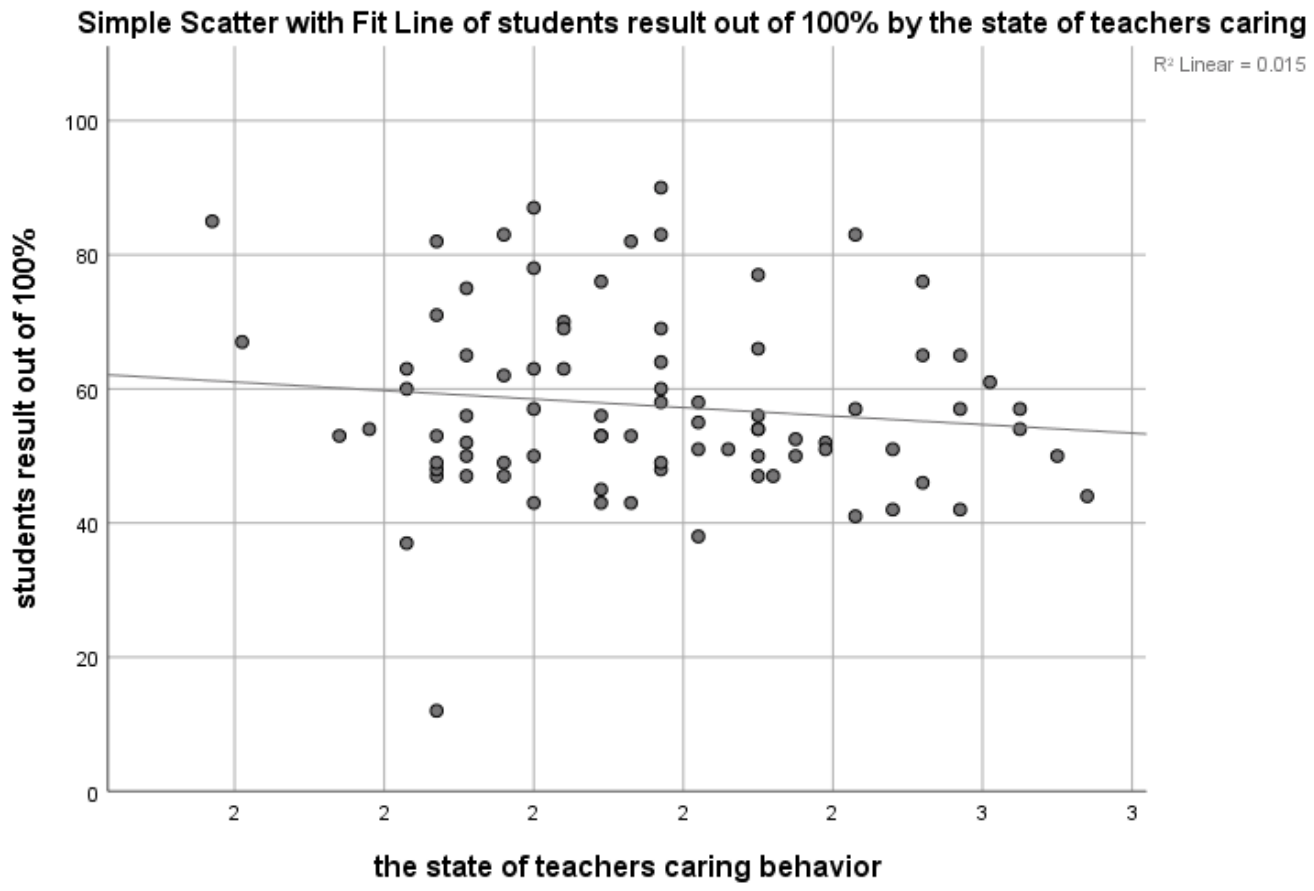

Chart 4.2: Male students scatter plot

To the other side when we see the case of female students, the correlation coefficient is 0.025 . Even though, 
the relation is very weak, the coefficient indicates that perceived teachers caring behavior has positive relation with students' achievement. This result is affiliated with many of the researchers in the area. For instance, Bulach (1998), Deiro (1996) and Noddings (1992) have noted that when students perceive their teachers as caring, their motivation to learn is positively influenced.

Table 4.6: Female students correlation result

\begin{tabular}{ll|r|r} 
& & caring behavior & students result out of $100 \%$ \\
\hline \multirow{2}{*}{$\begin{array}{l}\text { the state of teachers caring } \\
\text { behavior }\end{array}$} & Pearson Correlation & 1 & .025 \\
\cline { 2 - 4 } & Sig. (2-tailed) & 90 & .812 \\
\cline { 2 - 4 } & $\mathrm{N}$ & .025 & 90 \\
\hline \multirow{2}{*}{\begin{tabular}{l} 
students result out of $100 \%$ \\
\cline { 2 - 4 }
\end{tabular}} & Pearson Correlation & .812 & 1 \\
\cline { 2 - 4 } & Sig. (2-tailed) & 90 & 90 \\
\cline { 2 - 4 } & $\mathrm{N}$ & &
\end{tabular}

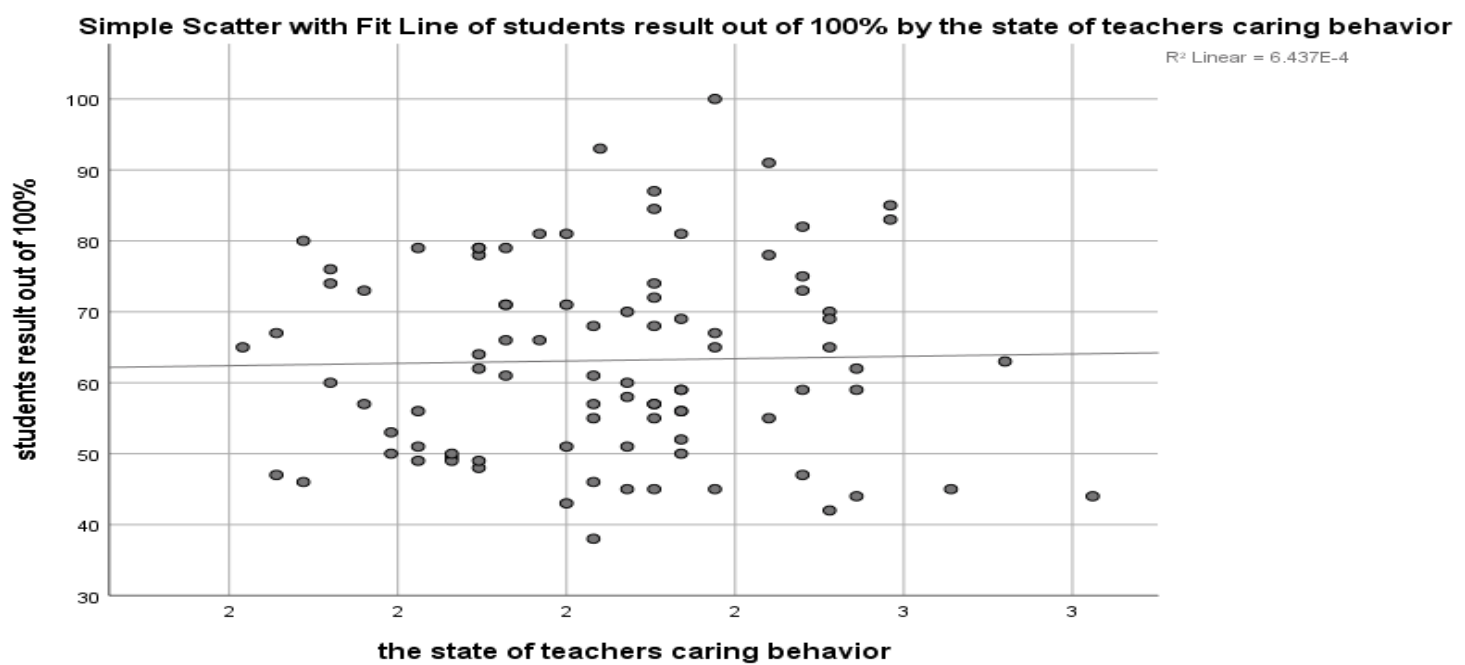

Chart 4.3: Female students scatter plot

\section{Conclusion}

Teachers caring behavior is an important factor for students learning and it is advocated by many Scholars in the world (Lake, Hass, \& Mathews, 2014; Noddings, 1992). Besides, studies of ( Owens \& Ennis, 2000 ; Davis, 2003) assert that students achievement is influenced by the state of caring behavior of teachers. When teachers demonstrate caring the students motivation to learn is increased and accordingly their achievement also increased (Noddings, 2008). Besides the low state of caring teachers caring behavior, the relation between perceived teachers caring behavior and students achievement is negative; and contradicts with the findings of many of the previously conducted empirical studies. In addition, difference is observed between the two sexes: while one is negative the other is positive. This would happen because of context difference. It is fact that context matters a lot and it has effect on trends, behaviors, and other attributes of human beings.

\section{Reference}

Abeya Geleta (2017).School Climate and Students achievement in Secondary Schools of Ethiopia. European Scientific Journal; V. 13; No. 17

Ayers, W. (1993). To teach: The journey of a teacher. New York: Teachers College Press

Bahar, G. (2014). The reciprocal relationship between teachers' caring qualities and students achievement: reality or Coincidence. Basic Research Journal of Education Research and Review. Vol. 3(2) pp. 13-18

Baker, K., \& Narula, B. (2012). The connected adolescent: Transitioning to middle school. Retrieved from http://files.eric.ed.gov/fulltext/EJ971418.pdf

Bulach, C. R., Brown, C., \& Potter, L. (1998). Behaviors that create a caring learning community. Journal for a Just and Caring Education, 4(4), $441-453$.

Deiro, J. (1996). Teaching with heart: Making healthy connections with students. Thousand oaks, CA: Corwin press

Frankel, J.R. and Wallen, N.E. (2006). How to Design and Evaluate Research in Education (6 ${ }^{\text {th }}$ ed.). New York: MC Graw Hill 
Garza, R. (2009). Latino and white high school students' perceptions of caring behaviors: Are we culturally responsive to our students? Urban Education, 44(3), 297-321. http://dx.doi.org/10.1177/0042085908318714

Gilligan, C. (1982). In a different voice. Cambridge, MA: Harvard University press

Goldstein, L. (1999). The relational zone: The role of caring relationships in the co-construction of the mind. The American Educational Research Journal, 36(3), 647-673. doi:10.2307/1163553

Knoell,C.M.(2012). The Role of the Student -Teacher Relationship in The Lives of Fifth Grader: A Mixed Methods Analysis. PhD. Dissertation, University of Nebraska

Kohn,A.(2006). Beyond discipline from Compliance to Community. Virginia: Association for supervision and Curriculum Development

Lambert, N. S. (1995). Perspectives of successful teachers reputed as caring: Explanations for connections in the classroom. American Journal of Education, 96(2), 2 15-230. Liston, D and Garrison, J. (2004).

Lumpkin, A. (2007). Caring teachers: The key to student learning. Kappa Delta Pi Record, V. 43 No. 4, 158 160.

EMoE.(2012). Professional Standard for Ethiopian Teachers.

Molalign Tamiru (2016). Teachers Caring Relationship with their Students: The case of Three Government Primary Schools in Addis Ababa. PhD Dissertation, AAU

Noblit, G., Rogers, D., \& McCadden, B. (1995). In the meantime: The possibilities of caring. Phi Delta Kappan, 76,680-685.

Noddings, N. (1988). An ethic of caring and its implications for instructional Behavior. Conference Paper.

Noddings, N. (1984) Caring: A feminine approach to ethics \& moral education. Berkeley: University of California Press.

Noddings, N. \& Shore, P. (1984). Awakening the inner eye: Intuition in education. New York: Teachers College Press.

Noddings, N. (1988). An ethic of caring and its implications for instructional arrangements. American Journal of Education, 96(2), 2 15-230.

Noddings, N. (1992). The challenge to care in schools: an alternative approach to education. New York: Teachers College Press.

Noddings, N. (1995). Philosophy of education. Dimensions of Philosophy series. Boulder, CO: Westview Press.

Palmer, P.J. (2007). The Courage to Teach: Exploring the Inner Landscape of a Teacher's Life.San Francisco: John Wiley \& Sons. Inc

Pianta, R.C., Hamere, B.K. and Allen, J.P. (2012). Teacher-Student Relationships and engagement: Conceptualizing, Measuring and Improving the Capacity of Classroom Interactions. Virginia: Springer Science

Sakiz, G. (2015). Perceived teacher factors in relation to students' achievement related outcomes in science classrooms in elementary school. European Journal of Science and Mathematics Education. Vol. 3, No. $2,2015,115-129$

Saltali,N.D.(2013). The teacher-student relationship as a predicator of preschoolers' social anxiety. Mevlana International Journal of Education,3(4). Sanders, P. (2000). Characteristics of effective teaching. URL

Stipek,D.(2006). Relationship Matters. Teaching to student strengths, 64(1), 46-49.

Teven, J.J. \& Mc Crosky, J.C.(1997).The Relationship of Perceived Teacher Caring with students learning and teacher education. Communication Education.

Thompson, S.W. (2010). The Caring Teacher: A Multiple Case Study That Looks at What Teachers Do and Believe about Their Work With At-Risk Students. University of Nebraska

Weissberg, R. P., Barton, H. A., \& Shriver, T. P. (1997). The social-competence promotion program for young adolescents." In G. W. Albee \& T. P. Gullotta (Eds.), Primary Prevention Works: The Lela Rowland Awards (pp. 268-90). Newbury Park, CA: Sage. 